Journal of Applied Pharmaceutical Science Vol. 2 (9), pp. 083-087, September, 2012

Available online at http://www.japsonline.com

DOI: $10.7324 /$ JAPS.2012.2917

ISSN 2231-3354 (cc) BY-NC-SA

\title{
Anticancer activity of ethanol extracts of P dygala rosmarinifolia Wight \& Arn whole plant against Dalton Ascites Lymphoma
}

\author{
Alagammal $\mathrm{M}^{1}$, Packialincy M. ${ }^{2}$ and Mohan V.R. ${ }^{2 *}$ \\ ${ }^{1}$ Government Siddha Medical College, Palayamkottai, Tamil Nadu. \\ ${ }^{2}$ Ethnopharmacology unit, Research Department of Botany, V.O.Chidambaram College, Tuticorin- 628008, Tamil Nadu.
}

\section{ARTICLE INFO}

Article history:

Received on: 30/08/2012

Revised on: 09/09/2012

Accepted on: 16/09/2012

Available online: 28/09/2012

Key words:

Polygala rosmarinifolia,

antitumor, lifespan, WBC.

\begin{abstract}
The present study aims to evaluate the antitumor activity of ethanol extract of whole plant of Polygala rosmarinifolia on DAL model in Swiss Albino mice. Evaluation of the antitumor effect of ethanol extract of whole plant of Polygala rosmarinifolia on tumor growth and host survival time was made by the study of the following parameters: tumor volume, viable and non viable cell count and life span of host. The results showed decrease in tumor volume and cell viability. Hematological studies revealed that, the Hb count decreased in DAL treated mice, whereas it was induced by the drug treated animals and showed an increase in $\mathrm{Hb}$ near to normal levels. The results suggested that the extracts of whole plant of Polygala rosmarinifolia exhibited significant antitumor activity on DAL bearing mice.
\end{abstract}

\section{INTRODUCTION}

Cancer is the abnormal growth of cells in our body that can lead to death. Cancer cells usually invade and destroy normal cells. More and more cancer research works have been done and yet we do not understand exactly what cancer is! (Estrogen , 2006). Cancer is the second leading cause of death in America. The major cause of cancer is smoking, diatery imbalances, hormones and chronic infections leading to chronic inflammation (Ames et al 1995). Plants have been used for treating various diseases of human beings and animals since time immemorial. They maintain the health and vitality of individuals and also cure diseases, including cancer without causing toxicity. More than $50 \%$ of all modern drugs in clinical use are of natural products, many of which have the ability to control

* Corresponding Author

Email:vrmohanvoc@gmail.com cancel cells (Rosangkima and Prasad , 2004). According to the estimates of the WHO, more than $80 \%$ of people in developing countries depend on traditional medicine for their primary health needs. A recent survey shows that more than $60 \%$ of cancer patients use vitamins or herbs as therapy (Madhuri and Pandy 2008: 2009). Polygala was traditionally used by Americans to treat snake bite (McGuffin et al, 1997) and as an expectorant to treat cough and bronchitis .In traditional Chinese medicine, Polygala is used for variety of purposes including the promotion to sleep and calming the sprit. Polygala is considered as a powerful tonic herb (Teegurarden, 1998) that can help to develop the mind and aid in creative thinking. Taking into consideration of the medicinal importance of Polygala rosmarinifolia, the ethanol extract of the whole plant of Polygala rosmarinifolia were analyzed for their anticancer activity against Dalton Ascites Lymphoma (DAL) tumor model. 


\section{MATERIALS AND METHODS}

\section{Collection}

The whole plants of Polygala rosmarinifolia Wight \& Arn were collected in the month of February and March, 2010, from the Vadavalli, Coimbatore district, TamilNadu. The plant specimen were identified with the help of local flora and authenticated in Botanical survey of India, Southern Circle, Coimbatore, Tamil Nadu, India. A voucher specimen was deposited in Ethnopharmacology Unit, Research Department of Botany, V.O. Chidambaram College, Tuticorin, Tamil Nadu.

\section{Preparation of plant extract for anticancer activity}

The whole plants of Polygala rosmarinifolia were cut into small pieces, washed dried at room temperature; the dried leaves and bark were powdered in a Wiley mill. Hundred grams of powdered leaf and bark were separately packed in a Soxhlet apparatus and extracted with ethanol. The ethanol extracts were concentrated in a rotary evaporator. The concentrated ethanol extracts of whole plant were used for anticancer activity.

\section{Animals}

Healthy male adult Swiss Albino mice (20-25gm) were used for the study. The animals were housed in microlon boxes in a controlled environment (temperature 25 $20 \mathrm{c}$ ) and $12 \mathrm{hr}$ dark/light cycle) with standard laboratory diet (Sai Durga feeds and foods, Bangalore) and water ad libitum. The mice well segregated based on their gender and quarantined for 15 days before the commencement of the experiment. They were fed on healthy diet and maintained in hygienic environment in our animal house.

\section{Tumor Cells}

Dalton Ascites Lymphoma (DAL) cells were obtained from Division of Oncology Department of Biotechnology, Tamil Nadu Veterinary and Animal Husbandry, Chennai, Tamil Nadu, India. The DAL cells were maintained in vivo in Swiss albino mice by weekly intra peritoneal (i. p) inoculation of $10^{6}$ cells / mouse after every ten days. DAL cells 9 days old were used for the screening of the anticancer activity.

\section{Acute oral toxicity study}

Acute oral toxicity was performed by following OECD guideline - 420 fixed dose procedure for ethanol extract of whole plant of Polygala rosmarinifolia and it was found that dose increasing up to $2000 \mathrm{mg} / \mathrm{kg}$ body weight, shown no toxicity or mortality in experimental mice. The LD50 of ethanol extracts of whole plant of Polygala rosmarinifolia as per OECD guidelines420 is greater than $2000 \mathrm{mg} / \mathrm{kg}$ (Ecobichon ,1997; Turner 1965).

\section{Antitumor activity}

Healthy Swiss albino mice were divided in to six groups of six animals $(n=6)$ each. The test samples were dissolved in isotonic saline $(0.9 \% \mathrm{NaCl} \mathrm{W} / \mathrm{V})$ and used directly in the assay.
DAL cells were collected from the donor mouse and were suspended in sterile isotonic saline. The viable DAL cells were counted (Trypan blue indicator) under the microscope and were adjusted at $1 \times 10^{6}$ cells/ ml. $0.1 \mathrm{ml}$ of DAL cells per $10 \mathrm{~g}$ body weight of the animals were injected (i. p) to each mouse of each group except normal saline group (Group I). This was taken as day 0 . Group I served as a normal saline control $(1 \mathrm{~mL} / \mathrm{kg}, \mathrm{p} . \mathrm{o})$ and group II served as DAL bearing control. On day 1, the ethanol extracts of Polygala rosmarinifolia at a dose of 100 and $200 \mathrm{mg} / \mathrm{kg}$ each of the Group III, IV were administrated orally and continued for 14 consecutive days respectively. Group V served as tumor induced animal administrated with vincristine $(80 \mathrm{mg} / \mathrm{kg}$ body weight) for 14 consecutive days. On day15, half of the animals $(n=3)$ in each case were sacrificed and the remaining animals were kept to observe the life span study of the tumor hosts. The effect of ethanol extract of Polygala rosmarinifolia on tumor growth and host's survival time were monitored by studying parameters like tumor volume, tumor cell count, viable tumor cell count, nonviable tumor cell count, mean survival time and increase in life span (Gothoskar and Ranadive 1975; Mazumder et al.,1997)

\section{Tumor growth response}

The effect of ethanol extracts of Polygala rosmarinifolia on tumor growth and hosts survival time were examined by studying the following parameters such as tumor volume, tumor cell count, viable tumor cell count, non viable tumor cell count, median survival time and increase in life span.

\section{Determination of Tumor volume}

The mice were dissected and the ascitic fluid was collected from the peritoneal cavity. The volume was measured by taking it in a graduated centrifuge tube. Packed cell volume was determined by centrifuging the ascitic fluid at $1000 \mathrm{rpm}$ for $5 \mathrm{~min}$.

\section{Determination of Tumor cell count}

The ascitic fluid was taken in a WBC pipette and diluted 100 times. Then a drop of the diluted cell suspension as placed on the Neubauer counting chamber and the number of cells in the 64 small squares was counted.

Estimation of viable and non viable tumor cell count (Tryphan blue dye assay)

The cells were then stained with tryphan blue $(0.4 \%$ normal saline) dye. The cells that did not take up the dye were viable and those that took the stain were non viable. These viable and non viable cells were counted.

\section{Percentage increase of life span (\% ILS)}

Animals were inoculated $\left(1 \times 10^{6}\right.$ cells $\left./ \mathrm{ml}\right) 0.1 \mathrm{ml}$ of DAL cells per $10 \mathrm{~g}$ body weight of the animals was injected (i.p) on day zero (day 0).A day of incubation was allowed for multiplication of the cells. Fourteen doses of the test samples $(100 \mathrm{mg} / \mathrm{kg}$ and 200 $\mathrm{mg} / \mathrm{kg}, 0.1 \mathrm{ml} / 10 \mathrm{~g}$ body weight) and control group was treated with same volume of saline $(0.9 \%$ sodium chloride solution) and 
compared with vincristine ( $80 \mathrm{mg} / \mathrm{kg}$ body weight) were injected i.p from the first day up to the 9 th day with $24 \mathrm{~h}$ intervals. The effect of ethanol extracts of whole plant of Polygala rosmarinifolia tumor growth was monitored by recording the mortality, daily for a period of 9 days and percentage increase in life span (\% ILS) was calculated from the following equation.

Increase in life span $=\mathbf{T}-\underline{\mathrm{C} X 100}$

\section{Body Weight}

Body weights of the experimental mice we recorded both in the treated and control group at the beginning of the experiment (zero day) and sequentially on every 5 th day during the treatment period.

\section{Hematological studies}

At the end of the experimental period, all mice were sacrificed by cervical dislocation. Blood was collected from freely flowing tail vein and used for the estimation of Hemoglobin content $(\mathrm{Hb})$, Red blood cell count (RBC) and White blood cell count (WBC). WBC differential count was carried out from Leishman stained blood smears ( Dacie and Lewis, 1958)

\section{Statistical analysis}

The data were analyzed using student's t- test statistical methods. For the statistical tests, $p$ values of less than 0.01 and 0.05 were taken as significant.

\section{RESULT}

The acute toxicity study, ethanol extracts of Polygala rosmarinifolia whole plant did not show any toxic effect up to the dose of $2000 \mathrm{mg} / \mathrm{kg}$ body weight, according $100 \mathrm{mg} / \mathrm{kg}$ and $200 \mathrm{mg} / \mathrm{kg}$ body weight were taken as low and high dose of whole plant Polygala rosmarinifolia for the experiment. The present investigation indicates that ethanol extracts of whole plant of Polygala rosmarinifolia showed significant antitumor activity in DAL becoming mice. The administration of ethanol extract of whole plant of Polygala rosmarinifolia to DAL bearing mice showed reduction in body weight, spleen, thymus, liver, kidney and lungs (Table 1). In the case of tumor growth response study, treatment with ethanol extract of whole plant of Polygala rosmarinifolia showed significant $(\mathrm{p}<0.01)$ reduction in tumor volume (Table 2). Table 3 depicts the effect of ethanol extract of whole plant of Polygala rosmarinifolia on life span, viable cell count and non viable cell count. It revealed that there was increase in mean survival time. Administration of ethanol extract of Polygala rosmarinifolia appreciably decreases the viable cell count compared to DAL bearing mice. Non viable cell count was significantly higher with increase in dosage of extracts. Table 4 showed that hematological parameters of tumor bearing mice on day 15 were found to be significantly different as compared to the extracts treated groups. In tumor bearing mice, it was found that there was increase in WBC count, and decrease in Hb content and $\mathrm{RBC}$ count. In differential count of WBC, present of neurophils and monocytes increased while the lymphocyte count decreased in the DAL control group. Treatment with Polygala rosmarinifolia whole plant at the dose $100 \mathrm{mg} / \mathrm{kg}$ and $200 \mathrm{mg} / \mathrm{kg}$ significantly ( $p<0.05$ and $\mathrm{p}<0.01$ respectively) increased the $\mathrm{Hb}$ and $\mathrm{RBC}$ count to normal levels. The total WBC count was found to be increased significantly in the DAL control group when compared to normal group. Administration of Polygala rosmarinifolia whole plant extracts $(100 \mathrm{mg} / \mathrm{kg}$ and $200 \mathrm{mg} / \mathrm{kg})$ in DAL bearing mice significantly $(p<0.05$ and $p<0.01)$ reduced the $\mathrm{WBC}$ count as compared with DAL control.

\section{DISCUSSION}

The present study was carried out to investigate the antitumor potential of whole plant of Polygala rosmarinifolia against DAL bearing mice. The ethanol extract treated animals at the doses of 100 and $200 \mathrm{mg} / \mathrm{kg}$ significantly inhibited the tumor volume, packed cell volume, tumor (viable) cell count and brought back the hematological parameters to more or less normal levels.

In DAL tumor bearing mice, a regular rapid increase in ascitic tumor volume was observed. Ascetic fluid is the direct nutritional source for tumor cells and rapid increase in ascitic fluid with tumor growth would be a means to meet the nutritional requirement of tumor cells (Prasad and Giri, 1994). Treatment with ethanol extract of Polygala rosmarinifolia inhibited the tumor volume, viable tumor cell count and increased the life span of the tumor bearing mice. The reliable criteria for judging the value of any anticancer drug are the prolongation of the life span of animals (Gupta et al., 2004). It may be concluded that ethanol extract of Polygala rosmarinifolia by decreasing the nutritional fluid volume and arresting the tumor growth increases the life span of DAL bearing mice. Thus, ethanol extract of Polygala rosmarinifolia has antitumor activity against DAL bearing mice. Usually, in cancer chemotherapy the major problems that are being encountered are of myelosuppression and anemia (Price and Greenfield, 1958; Hogland 1982; Rajeshwar et al., 2005). The anemia encountered in tumor bearing mice its mainly due to reduction in $\mathrm{RBC}$ or hemoglobin percentage, and this may occur either due to iron deficiency or due to hemolytic or myelopathic conditions (Rajeshwar et al., 2005; Sarada et al., 2012). Treatment with ethanol extract of Polygala rosmarinifolia whole plant brought back the hemoglobin $(\mathrm{Hb})$ content, $\mathrm{RBC}$ and $\mathrm{WBC}$ count more or less to normal levels. This clearly indicates that Polygala rosmarinifolia whole plant possess protective action on the hemopoietic system. Plant derived compounds have played an important role in the development of several clinical useful anticancer agents (Newman and Cragg, 2006). 1, 5 Anhydro-dmannitol, phytol, Didodeyl phthalate, squalene and 9-octadecenoic acid (Z)-phenyl methyl ester were reported in the ethanol extract of Polygala rosmarinifolia whole plant by GC-MS analysis. These compounds may have the role in anticancer property (Alagammal et al., 2012). Further, the isolation of the compounds responsible for the activity has to the taken up which may result in a modern drug from these plants. 
Table.1: Effect of ethanol extract of Polygala rosmarinifolia on Relative Organ Weights of tumor induced and drug treated mice.

\begin{tabular}{|c|c|c|c|c|c|c|}
\hline \multirow{2}{*}{ Treatment } & \multicolumn{6}{|c|}{ Relative Organ Weight (g/100g body wt.) } \\
\hline & Body weight (g) & Spleen & Thymus & Liver & Kidney & Lungs \\
\hline Group I & $20.14 \pm 1.75$ & $0.39 \pm 0.031$ & $0.10 \pm 0.037$ & $2.78 \pm 0.71$ & $0.93 \pm 0.20$ & $0.41 \pm 0.021$ \\
\hline Group II & $34.54 \pm 1.22^{\mathrm{a}}$ & $0.48 \pm 0.019$ & $0.19 \pm 0.051^{\mathrm{a}}$ & $3.41 \pm 0.58^{\mathrm{a}}$ & $1.86 \pm 0.11^{\mathrm{a}}$ & $0.68 \pm 0.032^{\mathrm{a}}$ \\
\hline Group III & $28.33 \pm 1.74 *$ & $0.36 \pm 0.014$ & $0.14 \pm 0.02$ & $3.12 \pm 0.36$ & $1.24 \pm 0.31$ & $0.56 \pm 0.031$ \\
\hline Group IV & $21.43 \pm 1.45^{* *}$ & $0.33 \pm 0.065$ & $0.12 \pm 0.022$ & $2.98 \pm 0.67$ & $1.03 \pm 0.43$ & $0.49 \pm 0.023$ \\
\hline Group V & $20.98 \pm 1.86 * *$ & $0.36 \pm 0.023$ & $0.14 \pm 0.015$ & $2.81 \pm 0.64$ & $1.09 \pm 0.029$ & $0.45 \pm 0.034$ \\
\hline
\end{tabular}

Each Value is SEM \pm 6 individual observations: $* \mathrm{P}<0.05 ; * * \mathrm{P}<0.01$; Compared to DAL control vs. drug treated groups

a : $\mathrm{P}<0.05$; Compared to DAL control vs. Normal Control

Table. 2: Antitumor activity of ethanol extract of Polygala rosmarinifolia on solid tumor volume in tumor Induced mice.

\begin{tabular}{lllll} 
& \multirow{2}{*}{ Treatment } & \multicolumn{3}{c}{ Solid Tumor Volume } \\
\cline { 2 - 5 } & $\mathbf{1 5}^{\text {th }}$ day & $\mathbf{2 0}^{\text {th }}$ day & $\mathbf{2 5}^{\text {th }}$ day & $\mathbf{3 0}^{\text {th }} \mathbf{d a y}$ \\
\hline Group II & $3.65 \pm 0.16$ & $3.98 \pm 0.27$ & $4.36 \pm 0.53$ & $4.98 \pm 0.53$ \\
Group III & $3.33 \pm 0.20^{*}$ & $3.40 \pm 0.11^{*}$ & $3.28 \pm 0.34^{*}$ & $3.06 \pm 0.28^{*}$ \\
Group IV & $3.12 \pm 0.36^{\mathrm{NS}}$ & $3.23 \pm 0.30^{*}$ & $3.12 \pm 0.63^{*}$ & $2.67 \pm 0.34^{* *}$ \\
Group V & $3.18 \pm 0.21^{\mathrm{NS}}$ & $3.04 \pm 0.14^{* *}$ & $2.63 \pm 0.53^{* *}$ & $2.31 \pm 0.49^{* *}$ \\
\hline
\end{tabular}

Each Value is SEM of 6 animals Significance between tumor induced control vs drug treated group $* \mathrm{P}<0.05 ; * * \mathrm{P}<0.01 ; \mathrm{NS}$ :Not significant

Table. 3 : Antitumor activity of ethanol extract of Polygala rosmarinifolia on the survival time, life span, tumor volume and viable and non-viable cell count in tumor Induced mice.

\begin{tabular}{llllll}
\hline Treatment & $\begin{array}{l}\text { Mean Survival time } \\
\text { (Days) }\end{array}$ & $\begin{array}{l}\text { Increase of life } \\
\text { span (\%) }\end{array}$ & $\begin{array}{l}\text { Packed cell } \\
\text { volume }\end{array}$ & $\begin{array}{l}\text { Viable cell count } \\
\mathbf{X ~ 1 0}^{6} \text { cells/ml }\end{array}$ & $\begin{array}{l}\text { Non-viable tumor } \\
\text { cells count X 10 }\end{array}$ \\
\hline Group II & $17.21 \pm 0.56$ & - & $3.20 \pm 0.031$ & $14.68 \pm 2.01$ & $0.83 \pm 0.031$ \\
Group III & $24.52 \pm 0.32$ & 42.48 & $1.12 \pm 0.021^{*}$ & $8.56 \pm 0.17^{*}$ & $1.94 \pm 0.16^{*}$ \\
Group IV & $29.85 \pm 0.78^{*}$ & 73.44 & $1.21 \pm 0.045^{*}$ & $7.91 \pm 0.21^{*}$ & $2.08 \pm 0.023^{*}$ \\
Group V & $30.68 \pm 0.45^{*}$ & 78.26 & $0.98 \pm 0.074^{* *}$ & $6.54 \pm 0.66^{* *}$ & $2.89 \pm 0.038^{*}$ \\
\hline
\end{tabular}

Each Value is SEM of 6 animals Significance between tumor induced control vs drug treated group $* \mathrm{P}<0.05 ; * * \mathrm{P}<0.01 ;$ NS :Not significant

Table . 4: Anticancer activity of ethanol extract of Polygala rosmarinifolia on hematological parameters in DAL Tumor bearing mice.

\begin{tabular}{|c|c|c|c|c|c|c|}
\hline \multirow{2}{*}{ Parameter } & \multirow{2}{*}{ Hb (gm \%) } & \multirow{2}{*}{ RBC (million/ $\mathbf{m m}^{3}$ ) } & \multirow{2}{*}{$\begin{array}{c}\mathrm{WBC} \\
\mathrm{f}^{3} \text { cells/ } \mathrm{mm}^{3} \text { ) }\end{array}$} & \multicolumn{3}{|c|}{ Differential count } \\
\hline & & & & Lymphocytes & Neutrophils & Eusinophill \\
\hline Group I & $14.34 \pm 0.46$ & $3.96 \pm 0.24$ & $9.67 \pm 0.68$ & $52.18 \pm 1.44$ & $43.81 \pm 0.97$ & $4.35 \pm 0.74$ \\
\hline Group II & $7.94 \pm 0.76^{* *}$ & $2.97 \pm 0.17 *$ & $16.56 \pm 0.95$ & $30.29 \pm 1.34$ & $62.32 \pm 1.51$ & $7.36 \pm 0.87$ \\
\hline Group III & $10.36 \pm 0.72 *$ & $3.46 \pm 0.12 *$ & $12.32 \pm 0.61 *$ & $39.36 \pm 1.56$ & $52.36 \pm 0.94$ & $5.68 \pm 0.36$ \\
\hline Group IV & $11.67 \pm 0.87 *$ & $3.97 \pm 0.12 *$ & $10.45 \pm 0.38 *$ & $45.58 \pm 1.52$ & $50.32 \pm 1.23$ & $4.01 \pm 0.22$ \\
\hline Group V & $13.04 \pm 0.55^{* *}$ & $4.13 \pm 0.65 * *$ & $8.91 \pm 0.33^{*}$ & $50.48 \pm 1.32$ & $41.23 \pm 1.37$ & $7.84 \pm 0.47$ \\
\hline
\end{tabular}

Each Value is SEM of 6 animals Significance between tumor induced control vs drug treated group $* \mathrm{P}<0.05: * * \mathrm{P}<0.01$ :

\section{ACKNOWLEDGEMENT}

The Authors wishes to thank Dr. R. Sampatharaj, Honorary Advisor, Samsun Clinical Research Laboratory, Tirupur, for their assistance in animal studies.

\section{REFERENCE}

Alagammal M., Tresina soris P. and Mohan V.R. GC-MS analysis of polygala rosmarinifolia Wights and Arn. J App Pharmaceu. Sci, 2012; 2: 188-190.

Ames B.N, Gold L.S and Willert W.G.The Causes and preservation of cancer. Proc. Natt. Acad. Sci.USA. 1995; 92: 5258-5265.

Dacie J.V and Lewis S.M. Practical Haematology $2^{\text {nd }}$ ed. J and A Churchill, London 1958; 38-40.

Ecobichon D.J. Fixed Dose ProcedureGuideline 420. The Basis of ToxicityTesting. 1997; II Edition, CRC Press: 43.

Estrogen and cancer website 2006. www.womenhealth.com. www. amazon.com.

Gothoskar S.V. and Ranadive K.J., Anticancer screening of SAN-AB; an extract of marking nut, Semicarps anacardium. Indian J Exp Biol.1975; 9: 372- 375.

Gupta M, Mazumder U.K, Rath N and Mukhopadhyay DK. J.Pharmacol. Sci., 2004; 94, 177-184.

Hogland H.C. Hematological Complications of Cancer Chemotherapy. Semin Oncol.1982; 9: 95-102.
Madhuri S and Pandey G .Some anticancer medicinal plants of foreign origin. Curr. Sci. 2009; 90: 779-783.

Maduri S and Pandey G. Some directly agricultural plants with anticancer properties. Plant Arch. 2008; 8: 13-16

Mazumder U.K., Gutpa M., Maiti S. and Mukherjee D., Antitumor activity of Gygrophila spinosa on Ehrlich Acsites Carcinoma and Sarcoma -180 induced mice, Ind.J. Exp.Biol. 1997; 35: 473-477.

Mc Guffin M, Hobbs C and R. Upton (eds). American Herbal Products Association's Botanical Safety Handbook. Boca Raton, FL: CRC Press, 1997; 89.

Newman D.J., Cragg G.M .and Sredei K.M. Natural products as sources of new drugs over the period 1981-2002, J Nat Prod.2006; 66: 1022-1037.

Prasad S.B and Giri A. Antitumor effect of C.splation against Murine ascites Dalton's lymphoma. Indian. J. Exp. Biol. 1994; 32: 155 162.

Price V.E and Greenfield R.E. Anemia in cancer. Adva.Cancer Res.1958; 5: 199-200.

Rajeshwar Y, Gupta M and Mazumder U.K. Antitumor activity and in vivo antioxidant status of Mucuana pruriens (Fabaceae) seeds against Ehrlich Ascites Carcinoma in Swiss Albino mice. Iranian J. Pharmmaco \&Therapeu.2005; 4: 46-53.

Rosangkima $G$ and Prasad S.B. Antitumor activity of some plants from Meghalaya and Mizoram against murine ascites Doltons lymphoma. India. J. Exp. Biol. 2004; 42: 981-988.

Sarada K, Jothibai Marget R and Mohan V.R. Anticancer activity of ethanol extract of leaf and bark of Naringi crenulata (Roxb) 
Nicolson against Ehrlich Ascites Carcinoma. Int. J. Res. Pharm. Chem. 2012; 2: 267-272.

Teeguarden R, Radiant Health: The Ancient Wisdom of the Chinese Tonic Herbs. New York: Warner Books, 1998; 194-95.

Turner R.A. Screening method in Pharmacology. Academic Press, NewYork. 1965; 299.
How to cite this article:

Alagammal M, Packialincy M. and Mohan V.R. Anticancer activity of ethanol extracts of Polygala rosmarinifolia Wight \& Arn whole plant against Dalton Ascites Lymphoma. J App Pharm Sci. 2012; 2(9): 083-087. 